Grand Valley State University

ScholarWorks@GVSU

January 2009

\title{
The Assessment of Patron-Initiated Collection Development via Interlibrary Loan at a Comprehensive University
}

Doug Way

Grand Valley State University, doug.way@gmail.com

Follow this and additional works at: https://scholarworks.gvsu.edu/library_sp

Part of the Library and Information Science Commons

\section{ScholarWorks Citation}

Way, Doug, "The Assessment of Patron-Initiated Collection Development via Interlibrary Loan at a Comprehensive University" (2009). Scholarly Papers and Articles. 5.

https://scholarworks.gvsu.edu/library_sp/5

This Article is brought to you for free and open access by the University Libraries at ScholarWorks@GVSU. It has been accepted for inclusion in Scholarly Papers and Articles by an authorized administrator of ScholarWorks@GVSU.For more information, please contact scholarworks@gvsu.edu. 


\title{
The Assessment of Patron-Initiated Collection Development via Interlibrary Loan at a Comprehensive University
}

\author{
DOUG WAY \\ Grand Valley State University Libraries, Allendale, Michigan, USA
}

\begin{abstract}
Patron-initiated collecting via interlibrary has been examined regularly in the literature over the past decade, with articles examining the topic at public libraries, liberal arts colleges, and large doctoral institutions. This paper examines a patron-initiated collection development program at Grand Valley State University, a comprehensive university with an enrollment of 24,000 students. It compares Grand Valley State University's experiences with those at other types of institutions. The paper also discusses the different models used to assess the success of these programs within the literature and how Grand Valley State University used WorldCat Collection Analysis, circulation statistics, and peer comparisons to assess its program.
\end{abstract}

KEYWORDS interlibrary loan, collection development, patroninitiated acquisitions

\section{INTRODUCTION}

Libraries today are implementing a number of forms of patron-initiated collection development. While the motivation and benefits to libraries vary, many see patron-initiated collection development as a way to take advantage of technology to move from just-in-case collecting to just-in-time collection development. In just-in-case collecting, libraries acquire materials anticipating that users may some day need an item, while in just-in-time collecting materials are not actually purchased until requested by a user. This kind of collecting in libraries is emerging through print-on-demand technology, through purchase-on-demand e-books, and through the use of patrons' interlibrary loan (ILL) requests.

Address correspondence to Doug Way, Head of Collection Development, Grand Valley State University Libraries, 1 Campus Dr., Allendale, MI 49401, USA. E-mail: wayd@gvsu.edu 
Patron-initiated collection development through ILL has been discussed regularly in the literature over the past decade. While there are examples from public libraries, liberal arts colleges, and research universities, there have been no articles about comprehensive universities using this form of collection development. Comprehensive universities tend to have an extensive number of graduate programs, but there is still an emphasis on teaching over research, and the highest degree granted is generally the master's degree. As a result, library collections at comprehensive universities often differ greatly from those at liberal arts or research institutions.

This article will examine the use of patron-initiated collection development via ILL at Grand Valley State University (GVSU), a comprehensive university in Allendale, Michigan. It will discuss GVSU's motivation for initiating the program, the process followed by the staff of the library in implementing the program, how the library is assessing it, and how these assessments' findings compare with the findings at other libraries.

\section{LITERATURE REVIEW}

Perdue and Van Fleet (1999) of Bucknell University were the first to discuss patron-initiated collection development via ILL. A liberal arts college, Bucknell began the program in 1990 to reduce the number of ILL transactions and build "equity in the library collection" (Perdue \& Van Fleet, 1999). Any books requested through ILL were rush-ordered by the library. Perdue and Van Fleet used subsequent circulations to evaluate the program. They found that the books purchased circulated at a higher rate than titles acquired by the library and deemed the program a success (Perdue \& Van Fleet, 1999).

Subsequent articles examined similar programs at both public libraries and research institutions. Programs at public libraries were developed with a variety of goals, including obtaining titles more quickly than was possible through ILL, decreasing the number of ILLs, improving ILL fill rates, and increasing patron satisfaction (Allen, Ward, Wray, \& Debus-López, 2003; Campbell, 2006; Hulsey, 2003). The libraries used a variety of criteria in deciding what books would be acquired. One library purchased all requested in-print and out-of-print titles (Hulsey, 2003). At other libraries a variety of criteria were used, including price, subject matter, age, availability, and previous requests (Allen et al., 2003; Campbell, 2006). Assessment was not discussed extensively in these articles, but where it was, cost savings over ILL, turnaround time and subsequent circulations were viewed as important measures (Allen, 2003; Hulsey, 2003).

As at public libraries, the programs at research universities used a variety of criteria to determine what books should be purchased. They also use a variety of criteria to examine the successfulness of their programs. Like the program at Bucknell and some of the public libraries, subsequent 
use following the initial use was seen as an important indicator of success. Many institutions were also very concerned with examining whether the titles purchased were appropriate for their libraries' collections.

Some programs at research institutions were very limited in scope. The University of Minnesota Law Library implemented a program that used an extensive list of criteria to determine whether to acquire a requested book. The criteria included cost, turnaround time, appropriateness to the collection, previous requests, availability via ILL, publication date, and material type (Zopfi-Jordan, 2008).

The University of Arkansas Libraries instituted a program where they purchased individual papers published in a specific series that was regularly borrowed through ILL, but the entire series was too expensive for the university to acquire as a whole (Gibson \& Kirkwood, 2009). To evaluate the program, the authors extrapolated potential cost savings and examined subsequent circulations of the purchased titles. Using these criteria, the authors determined that the program was a success and were considering expanding it to include other series.

While the programs at the University of Minnesota Law Library and the University of Arkansas were more limited in scope than those at other libraries in the literature, most libraries placed limits on what materials to purchase. Purdue University implemented a program that required books be English language, scholarly, nonfiction, published within the previous five years, available to be shipped within one week, and costing no more than $\$ 150.00$ (Allen et al., 2003; Anderson et al., 2002; Ward, 2002; Ward, Wray, \& Debus-Lopez, 2003). Most other research libraries had similar requirements but also placed additional limits on what they would acquire. The University of Hong Kong Libraries limited their purchases to those titles that they would have to borrow from an overseas library (Chan, 2004). The University of Florida limited its purchases to requests from faculty, graduate students, and distance students (Foss, 2007), while Brigham Young University limited its purchasing to only those titles requested by faculty (Alder, 2007). The University of Wisconsin-Madison purchased books requested by any user but primarily limited its program to those titles that were not easily filled using ILL (Allen et al., 2003; Ward et al., 2003). Pennsylvania State University Libraries closely followed the University of Wisconsin-Madison's model but limited their purchases to those titles they would have received through their approval plan (Coopey \& Snowman, 2006).

Just as the research libraries used a variety of criteria to determine what books they would acquire, they also used a variety of criteria to evaluate the success of their programs. These included objective measures such as turnaround time and the cost effectiveness of purchasing the titles compared with borrowing the books, as well as more subjective measures including surveys of users, library staff, and library administrators (Allen et al., 2003; Chan, 2004; Coopey \& Snowman, 2006; Foss, 2007). 
As at Bucknell, one objective measure used by many of the libraries to evaluate the success of their programs was subsequent circulations. More than half the books acquired by Hong Kong University circulated more than once (Chan, 2004). The University of Arkansas found that the items purchased in their program were as likely to circulate as other items traditionally acquired materials (Gibson \& Kirkwood, 2009), while the University of Wisconsin-Madison and Purdue University both found that books acquired through their programs circulated at a significantly higher rate than traditionally acquired books (Ward, 2002; Ward et al., 2003). While the rate of subsequent circulations varied, all of these libraries felt that the results from using this measure showed that their programs were successful.

A common subjective evaluation method discussed in the literature was to have subject librarians or bibliographers evaluate the appropriateness of the books acquired, often using their collection development policies as a basis for that evaluation. Purdue University and Hong Kong University both had librarians review the titles purchased in their programs to determine if they fit with the libraries' collections, while the University of Wisconsin-Madison indicated that they would be conducting this kind of evaluation in the future (Allen et al., 2003; Anderson et al., 2002; Chan, 2004). Purdue University found that the vast majority of books purchased were of the same quality as those titles bibliographers had firm ordered (Anderson et al., 2002). Hong Kong University found that $95 \%$ of books acquired were within the scope of the library's collection development policy (Chan, 2004). The libraries that employed this method of evaluation felt these findings reflected positively on the ILL purchase program. The difficulty with this method of evaluation is that it is not generalizable to other institutions, and the appropriateness of a book may vary from librarian to librarian even at the same institution.

\section{BACKGROUND}

GVSU is a comprehensive university with approximately 24,000 students and more than 200 undergraduate areas of study and 27 graduate programs almost entirely at the master's level. With a wide variety of programs, an emphasis on faculty teaching over research, and with graduate studies generally focused on professional programs in areas such as health care, education, and business, libraries at comprehensive universities like GVSU generally focus on having current collections that emphasize breadth of coverage over depth. Liaison librarians normally serve more than one major or program and are often generalists who may have limited expertise in many of the areas they serve.

The librarians at GVSU follow standard academic library practices in identifying and purchasing monographs to support student learning and faculty research. These include the use of slip and approval plans, review 
publications, standard lists, and faculty recommendations. Still, in the past six years only $31 \%$ of the library's book collection has circulated. At the same time there has been a dramatic increase in the use of ILL. Overall, ILL has increased by 330\% over the past five years, with a $291 \%$ increase in book borrowing during that same period.

Seeing the use of ILL as an indicator of unmet demand, the library began to look toward patron-initiated collecting as a way to identify works that would enhance the library's collections. The library used the ILL analysis in WorldCat Collection Analysis (WCA) to generate a list of titles that had been borrowed over the past year. WCA is a utility developed by OCLC that allows libraries to compare their holdings to the WorldCat catalog, other libraries and standard bibliographic lists. It also allows for an analysis of ILL data pulled from ILLiad and of circulation data that libraries are able to upload from their integrated library systems. A cursory review of the list pulled from WCA seemed to indicate a large number of the titles would likely be appropriate for the collection. As a result, the library decided to pursue the development of a patron-initiated purchase program via ILL to enhance the library's collection.

After reviewing the literature to examine the practices at other institutions, GVSU developed a variety of scenarios and ran a number of queries in WCA's ILL analysis to gather data for developing an initial budget. The library settled on a $\$ 5,000.00$ budget and limited purchases to in-print monographs published in the past 3 years costing $\$ 75.00$ or less. The $\$ 75.00$ price limit was put into place primarily to prevent the purchasing of textbooks. The process set up at GVSU had no librarian review, and there was anecdotal evidence from the ILL staff that students regularly tried to request textbooks, an item-type that was generally not collected by the library.

The program was tested for one semester to iron out any issues, and it was fully implemented at the start of the next academic year. Almost immediately, the ILL department requested the program be changed to include media that met all other criteria into the program. Acquiring media, especially videos, via ILL was a challenge for the department, so this change was implemented. A second issue that arose was that the number of titles purchased through the program was initially lower than anticipated. After discussing this issue with the ILL department, it was discovered that book requests were being submitted to other libraries automatically and that a setting in ILLiad had to be changed in order for the ILL staff to view the book requests.

\section{RESULTS AND ANALYSIS}

GVSU looked at a variety of measures to analyze the first year of its ILL purchase program, including subsequent circulations and the holdings of peer 
TABLE 1 Summary of Titles Purchased by Status of Requestor

\begin{tabular}{lcc}
\hline Status & $\begin{array}{c}\text { Number of } \\
\text { titles purchased }\end{array}$ & $\begin{array}{c}\text { Percent of } \\
\text { total }\end{array}$ \\
\hline Faculty & 59 & $51.75 \%$ \\
Staff & 2 & $1.75 \%$ \\
Graduate & 11 & $9.65 \%$ \\
Undergraduate & 41 & $35.96 \%$ \\
Unknown & 1 & $0.88 \%$ \\
\hline
\end{tabular}

institutions. The library used data pulled from the library's integrated library system, ILLiad, and WorldCat Collection Analysis to aid in its examination of the program. It also examined the titles selected by various constituencies, including faculty, staff, undergraduate students, and graduate students. The majority of the users requesting titles that were purchased were faculty members, with the next largest group being undergraduate students. Graduate students made up a much smaller percentage of the requests. Table 1 shows the distribution of titles acquired based on requests, broken down by the status of the person making the request.

\section{Circulation Analysis}

In the first full year of the program, 114 items were purchased. Of those items, 6 were video recordings and 108 were books. There were 41 items that circulated more than once. The items acquired circulated an average of 1.5 times each, with the highest circulating item being checked out 9 times over the course of the year and with 12 requested items never circulating. Table 2 illustrates the circulation data by the status of the requestor, including the total number of circulations for all titles, data on the number and percentage of titles that circulated more than once, and the percentage of requests that never circulated.

TABLE 2 Circulation Data by Status of Requestor

\begin{tabular}{|c|c|c|c|c|}
\hline Status & $\begin{array}{c}\text { Total } \\
\text { circulations }\end{array}$ & $\begin{array}{c}\text { \# with } \\
\text { subsequent } \\
\text { circulations }\end{array}$ & $\begin{array}{l}\text { \% with } \\
\text { subsequent } \\
\text { circulations }\end{array}$ & $\begin{array}{c}\% \text { of requests } \\
\text { with zero } \\
\text { circulations }\end{array}$ \\
\hline Faculty & 78 & 20 & $34 \%$ & $5 \%$ \\
\hline Staff & 10 & 1 & $50 \%$ & $0 \%$ \\
\hline Graduate & 23 & 6 & $45 \%$ & $27 \%$ \\
\hline Undergraduate & 57 & 14 & $34 \%$ & $15 \%$ \\
\hline Unknown & 1 & 0 & $0 \%$ & $0 \%$ \\
\hline Total & 169 & 41 & $36 \%$ & $11 \%$ \\
\hline
\end{tabular}




\section{Peer Comparisons}

It was felt that it was important to determine whether the books acquired were typically acquired for a comprehensive university's library collection. At a number of institutions, subject liaisons or bibliographers reviewed purchases to determine their appropriateness. The subjective nature of this process did not seem appropriate for a comprehensive university where breadth in library collections generally takes precedence over depth of coverage. Every year there are thousands of published titles that may be appropriate for the library's collection, but they are not acquired because of a variety of factors including limited budgets and existing coverage in a subject area. Moreover, the subjective nature of this kind of analysis would make it difficult to benchmark and to make comparisons over time. With this in mind, the library decided to use peer holdings of the same work as a benchmark.

Because budgets can vary widely, the library used data from the National Center for Education Statistics' (NCES) Library Statistics Program to identify those peer institutions with similar book budgets. Using the "Expenditures: Books, Serial Backfiles, Other Materials" category in the NCES Library Comparison Report, five universities were identified from an initial pool of 10 peers (National Center for Education Statistics, 2006). These universities were the University of Nebraska at Omaha, Portland State University, Appalachian State University, James Madison University, and Boise State University.

Using the WorldCat catalog, each library's holdings were checked to determine if the books purchased through the ILL program were owned by that library. This survey found that 59\% of the purchased titles were owned by at least one of the peer institutions and that $36 \%$ of the titles were owned by more than one peer institution. To examine how these percentages compared to library holdings as a whole, a comparison group was created in WCA using the same libraries. The analysis was limited to items with a book format and an adult audience level that had been published since 2006. This covered those titles eligible for the ILL purchase program. A review of the data showed that $60 \%$ of the items examined that were owned by GVSU were also owned by at least one of the peer institutions, while $22 \%$ of the titles were owned by more than one peer institution. When the format limiter was expanded to include visual materials, the analysis found that 59\% of the items were owned by at least one peer institution, and $22 \%$ of the titles were owned by more than one.

An analysis was also done to determine whether any group of requestors did a better job selecting titles that would be held at peer institutions. Table 3 shows the two groups that made the most requests, faculty and undergraduates, and the number of titles each selected that were held by peer institutions.

Another analysis was done to examine the circulation of titles owned by peer institutions. Table 4 shows that items owned by at least one peer 
TABLE 3 Peer Comparisons by Status of Requestor

\begin{tabular}{lcc}
\hline & Faculty & Undergraduate \\
\hline \# of requests held by more than one peer & 20 & 13 \\
$\%$ of requests held by more than one peer & $34 \%$ & $32 \%$ \\
\# of requests held by no peers & 25 & 19 \\
$\%$ of requests held by no peers & $42 \%$ & $46 \%$ \\
\hline
\end{tabular}

institution circulated more often than those not owned by a peer. Items owned by multiple peers circulated at an even higher rate. It also shows that items owned by multiple peers were more likely to have subsequent circulations than items owned by one or no peers.

\section{DISCUSSION}

The overall results of the analysis of the ILL purchase program seem to indicate that it is an effective way to supplement subject liaisons' traditional collection development activities. The titles acquired were generally appropriate for the library's collection and are in demand by library users.

\section{Circulation}

As with the studies at other colleges and universities, GVSU found that the books acquired through the ILL purchase program circulated at a higher rate than books traditionally acquired. The percentage of titles that had subsequent circulations was lower than that at some institutions. Still, the fact that $36 \%$ of the books had at least one subsequent circulation in the first year they were purchased bodes well for the future use of those titles. This is especially true when one considers that only $19 \%$ of books traditionally acquired during that same period of time circulated at all. The circulation of these items will still need to be examined over time to determine if they continue to circulate and if the percentage of purchased items with subsequent circulations increases.

TABLE 4 Circulation Data by Peer Holdings

\begin{tabular}{lcccc}
\hline & $\begin{array}{c}\text { Total } \\
\text { circulations }\end{array}$ & $\begin{array}{c}\text { Avg. } \\
\text { circs./item }\end{array}$ & $\begin{array}{c}\text { Titles w/subsequent } \\
\text { circulations }\end{array}$ & $\begin{array}{c}\text { \% holdings group w/ } \\
\text { subsequent circs. }\end{array}$ \\
\hline $\begin{array}{l}\text { No peer holdings } \\
\text { Held by at least } \\
\text { one peer }\end{array}$ & 62 & 1.31 & 14 & $30 \%$ \\
$\begin{array}{c}\text { Held by more } \\
\text { than 1 peer }\end{array}$ & 76 & 1.60 & 28 & $42 \%$ \\
\hline
\end{tabular}


The fact that 12 titles never circulated was not surprising. The library had anecdotal evidence that a certain percentage of items and articles requested through ILL were never picked up or used. The distribution of requestors who never picked up items included faculty, graduate students, and undergraduate students. This same issue was reported at Bucknell, although in their study, which examined a longer period of time, a smaller percentage of books never circulated (Perdue \& Van Fleet, 1999). Further examination of this issue over time will hopefully provide both some evidence as to whether these requested books will subsequently circulate and also perhaps some insight into the scope of the problem related to ILL items that are never used.

\section{Peer Comparison}

The circulation data for titles held by peer institutions would seem to support the notion that using peer holdings is a way to identify titles that may be needed by library users. In this study, titles owned by one peer circulated at a higher rate than titles owned by no peers. Moreover, titles owned by two or more peers circulated at a higher rate than titles owned by only one peer. Further study with a larger sample is necessary before discussing the reliability or generalizability of this kind of measure, but the initial findings support the idea of this being a more objective measure of the appropriateness of a title.

The analysis of peer holdings showed that the percentage of patroninitiated purchases held by peer institutions was equivalent to the percentage of traditionally acquired purchases. This would suggest patrons were generally able to identify works that were appropriate for a comprehensive university.

The results of this study also showed that the books requested by undergraduates were almost as likely to be held by peer institutions as those requested by faculty members. This is important because, unlike the University of Florida and Purdue University where the vast majority of requestors were faculty and graduate students (Foss, 2007; Ward, 2002), or at Brigham Young University where faculty were the only users for whom books were purchased (Alder, 2007), undergraduate students are the largest users of ILL at GVSU.

\section{CONCLUSION}

The results of the ILL purchase program at GVSU indicate that this program is an effective way to enhance the library's collections. The library plans on continuing the program in the future and will look at expanding the program by either increasing the price limit on titles or expanding the date range of titles eligible to be purchased. While this program by itself will never completely replace traditional collection development, as technologies 
evolve, libraries will be able to place more and more of the work of collection development into the hands of their patrons. Whether through the use of e-books, print-on-demand technology, or through purchase-on-demand programs such as the one discussed in this article, these initiatives move libraries from just-in-case purchasing to a new model that make more efficient use of libraries' budgets and librarians' and library staffs' time and effort.

\section{REFERENCES}

Alder, N. L. (2007). Direct purchase as a function of interlibrary loan: Buying books versus borrowing. Journal of Interlibrary Loan, Document Delivery E Electronic Reserve, 18(1), 9-15.

Allen, M., Ward, S. M., Wray, T. \& Debus-López, K. E. (2003). Patron-focused services in three U.S. libraries: Collaborative interlibrary loan, collection development and acquisitions. Interlending \& Document Supply, 31, 138-141.

Anderson, K. J., Freeman, R. S., Hérubel, J. V. M., Mykytiu, L. J., Nixon, J. M., \& Ward, S. M. (2002). Buy, don't borrow: Bibliographers' analysis of academic library collection development through interlibrary loan requests. Collection Management, 27(3/4), 1-11.

Campbell, S. A. (2006). To buy or borrow, that is the question. Journal of Interlibrary Loan, Document Delivery E Electronic Reserve, 16(3), 35-39.

Chan, G. (2004). Purchase instead of borrow: An international perspective. Journal of Interlibrary Loan, Document Delivery \& Information Supply, 14(4), 23-37.

Coopey, B. M., \& Snowman, A. M. (2006). ATG special report-ILL purchase express. Against the Grain, 18(1), 46-49.

Foss, M. (2007). Books-on-demand pilot program: An innovative "patron-centric" approach to enhance the library collection. Journal of Access Services, 5(3), 305-315.

Gibson, T. M., \& Kirkwood, P. E. (2009). A purchase-on-demand pilot project at the University of Arkansas, for the Proceedings of the Materials Research Society Symposiums. Journal of Interlibrary Loan, Document Delivery \& Electronic Reserve, 19, 47-56.

Hulsey, R. (2003). Purchase on demand: A better customer service model. Library Journal, 128(10), 77.

National Center for Education Statistics, Library Statistics Program. (2006). Academic libraries survey [Data file]. Retrieved from http://nces.ed.gov/surveys/libraries.

Perdue, J., \& Van Fleet, J. A. (1999). Borrow or buy? Cost-effective delivery of monographs. Journal of Interlibrary Loan, Document Delivery \& Information Supply, 9(4), 19-28.

Ward, S. M. (2002). Books on demand: Just-in-time acquisitions. The Acquisitions Librarian, 27, 95-107.

Ward, S. M., Wray, T., \& Debus-Lopez, K. E. (2003). Collection development based on patron requests: Collaboration between interlibrary loan and acquisitions. Library Collections, Acquisitions, and Technical Services, 27(2), 203-213.

Zopfi-Jordan, D. (2008). Purchasing or borrowing: Making interlibrary loan decisions that enhance patron satisfaction. Journal of Interlibrary Loan, Document Delivery E Electronic Reserves, 18(3), 387-394. 